\title{
Effects of hydrographic and meteorological factors on seasonal seabird abundance in the southern North Sea
}

\author{
Stefan Garthe ${ }^{1, *}$, Nele Markones ${ }^{1}$, Ommo Hüppop ${ }^{2}$, Sven Adler ${ }^{1,3}$ \\ ${ }^{1}$ Research and Technology Centre (FTZ), University of Kiel, Hafentörn 1, 25761 Büsum, Germany \\ ${ }^{2}$ Institute of Avian Research 'Vogelwarte Helgoland', Island Station, PO Box 1220, 27494 Helgoland, Germany \\ ${ }^{3}$ Institute for Biosciences, General and Systematic Botany, Wismarsche Straße 8, 18057 Rostock, Germany
}

\begin{abstract}
We examined the influence of both season and hydrographic and meteorological factors on seabird abundance in the southern North Sea. Seabirds were counted from ships in a study area of $27.8 \times 32.8 \mathrm{~km}$ on $407 \mathrm{~d}$ from 1990 to 2007 . Two hydrographic and 5 meteorological parameters were taken from archived data. The relationships between bird abundance and abiotic parameters were investigated by generalised additive models for 3 distinct seasons. The species in the study area exhibited different seasonal patterns. While some species were present year-round, others occurred only at certain periods. Despite these substantial changes in abundances, the nature of the interactions between bird abundances and abiotic parameters did not vary much between seasons. All 5 meteorological and 2 hydrographic parameters significantly influenced the abundance of seabird species, though to a different degree. The single factors that most often had a significant influence in the single models were wind field, sea surface temperature anomaly, sea surface salinity anomaly and air pressure change. The quantitative composition of the seabird community differed significantly between onshore wind and offshore wind conditions. It is assumed that hydrographic parameters are relevant for the birds by determining their foraging habitats and that atmospheric parameters influence flight conditions during foraging and migration.
\end{abstract}

KEY WORDS: Seabird · Hydrography $\cdot$ Meteorology $\cdot$ Phenology $\cdot$ Wind $\cdot$ Monitoring Resale or republication not permitted without written consent of the publisher

\section{INTRODUCTION}

Various studies have investigated the influence of abiotic and biotic factors on the distribution and abundance of seabirds at sea (for reviews see Hunt 1990, Schneider 1991). Processes involved vary from 100s of metres to 1000 s of kilometres in spatial ranges and from hours to years in temporal ranges, reflecting the influence of different oceanographic features and processes affecting prey availability to seabirds (Hunt \& Schneider 1987). Less attention has been paid to the influence of meteorological factors, except for wind direction and wind speed (Furness \& Bryant 1996, Weimerskirch et al. 2000). Recent advances in global weather data availability have enabled analyses of how seabirds cope with large-scale weather patterns, e.g. the use of low and/or high pressure systems for movements and foraging flights (Nicholls et al. 1997, Spruzen \& Woehler 2002). However, at small temporal and spatial scales, little is known about the respective effects of hydrographic and meteorological factors on seabird abundance, namely in coastal areas with high environmental variability, such as the southeastern North Sea (Markones et al. 2008). There, in particular, Larus spp. gulls often show highly divergent patterns on a day to day basis. This could be expected, to some degree, since the study area in question, the Inner German Bight, is an area of very high hydrographic variability, comprising the transition zone between the less saline and turbid Continental Coast Water Mass and the more saline and transparent Central North Sea Water Mass (Becker et al. 1983). In this system, fresh- 
water influx is enhanced during offshore easterly and southerly winds, while seawater influence is increased when westerly winds occur. Garthe (1997) and Markones (2007) showed that the distribution of several seabird species correlated with the occurrence of these 2 main water masses. The nearshore-dominating Continental Coast Water Mass was the preferred habitat of common gulls Larus canus, while northern fulmars Fulmarus glacialis, black-legged kittiwakes Rissa tridactyla and common guillemots Uria aalge were significantly associated with the Central North Sea Water Mass, which becomes dominant in the deeper northwestern part of the study area. Changes in bird assemblages may be a consequence of sometimes rapid

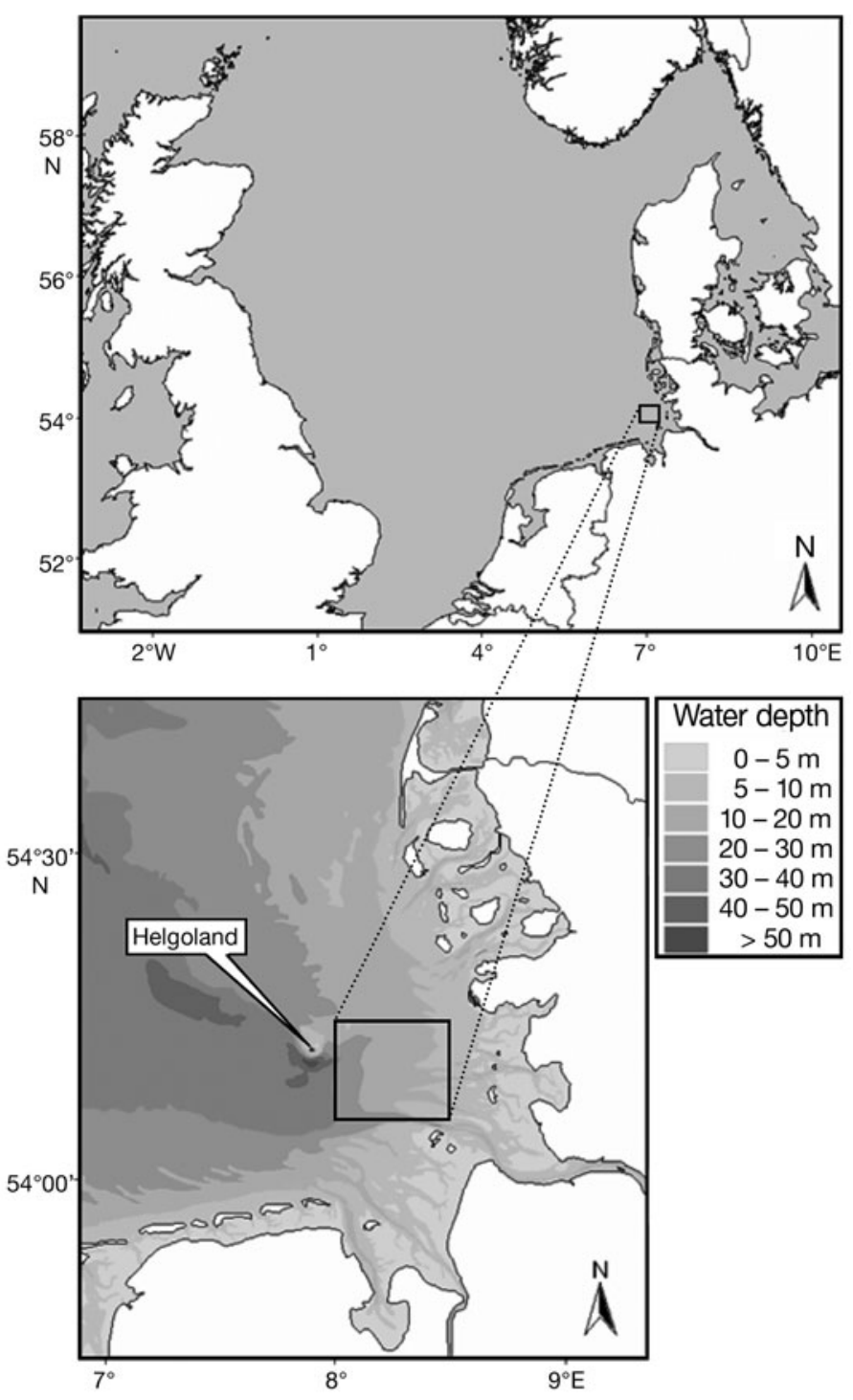

Fig. 1. Location of the study area 'HELBOX' (Helgoland box). The upper panel shows the location in the North Sea; the lower panel shows more details from the southeastern North Sea. The label 'Helgoland' represents both the island and the station 'Helgoland Roads' variations in hydrographic and/or meteorological parameters. Also, species may differ in their response to these changes, as well as in their choice of habitat, especially pelagic versus coastal seabirds. Furthermore, habitat requirements of seabirds undergo a seasonal pattern. During the breeding period, the activity range of birds is restricted by the availability of suitable nest sites and parental duties (incubation shifts and chick provisioning). During spring and autumn, distribution patterns are often influenced by moulting, migration, or dispersal (Stone et al. 1995). In winter, movements are generally less pronounced, though, e.g., cold spells may induce some movement, especially in waterfowl species (Elkins 1988, Ridgill \& Fox 1990). In consequence, different influences of abiotic factors on the distribution and abundance patterns of seabirds among the different seasons may occur (Markones 2007).

In the present paper, we thus investigate to what degree seasonal, hydrographic and meteorological factors influence seabird abundance in the Inner German Bight (southern North Sea). We concentrate our efforts on an intensively surveyed study site at the transition between coastal and marine influences. A high level of survey effort has been carried out under variable environmental conditions. We relate key hydrographic and atmospheric parameters to bird abundance to assess which factors predominantly influence the abundance of the different seabird species during different seasons. We also investigate whether these factors may influence seabird community composition. Finally, we evaluate the consequences of our findings for seabird monitoring programs, processes of selection and delineation for marine protected areas and climate change predictions.

\section{MATERIALS AND METHODS}

Study area. The study area is a $27.8 \times 32.8 \mathrm{~km} \mathrm{rec}-$ tangular area located to the east of the island of Helgoland in the Inner German Bight (hereafter 'HELBOX'; Fig. 1). Both bird and environmental data were assembled for each day of ship-based observations, which covered at least $5 \mathrm{~km}^{2}$ within the box area $\left(5 \mathrm{~km}^{2}\right.$ as a minimum equals $1 \mathrm{~h}$ of counts at a ship speed of 9 knots and with $17 \mathrm{~km}$ of linear survey effort).

Bird data. Birds at sea were counted from ships, following the current international standard (Tasker et al. 1984, Camphuysen \& Garthe 2004). All species were recorded within a transect strip of $300 \mathrm{~m}$ width set perpendicular to one or both sides of the steaming vessel. The width of $300 \mathrm{~m}$ was estimated according to the range-finding method of Heinemann (1981) using callipers. For swimming individuals, the transect strip was 
subdivided into 4 bands (0 to 50, 50 to 100,100 to 200 and 200 to $300 \mathrm{~m}$ ) to allow for distance corrections. As flying birds move faster than the observation vessel, we used the snapshot method described by Tasker et al. (1984) to avoid overestimation of particularly mobile species. According to this technique, flying birds are, by convention, only recorded as within the transect when they fly over the area of the transect strip at the time of a snapshot count. Flying birds crossing the transect strip at other times and birds sighted outside the transect area were usually also recorded, but their numbers were not used for density calculations. During all surveys, geographic positions were automatically recorded every minute with a hand-held GPS (global positioning system)-recorder. Counts were only conducted and used for analysis when visibility was good enough to survey the entire transect area and beyond (minimum visibility: $1 \mathrm{~km}$ ) and when other weather conditions such as wind, rain and spray did not influence the counts.

To account for birds that were overlooked, especially in the outer transect area on the water, we applied the distance sampling methodology and calculated species-specific correction factors to estimate detection probability. To take into account clustering of birds (group sizes per observation), the time unit for analysis was set at a 1 min counting interval. We applied the half-normal function with cosine adjustment using the software Distance 5.0 (Thomas et al. 2006). Only for this analysis, were data based on all records from within the German Bight (not only from the HELBOX) since 1993. As the detectability of birds on water (i.e. birds that are swimming, resting, preening, etc.) changes with wave heights and white crests on the water (Duffy 1983), correction factors were calculated separately for each sea state. Sea states are coded to describe wave height and white water conditions
(Beaufort scale; Dietrich et al. 1975). As sea state is recorded continuously during all bird counts, such a correction procedure takes into account the frequently changing conditions at sea. For species with low sample sizes and for sea states experienced rarely or with similar effects on detectability, correction factors were summarised for $>1$ sea state value. Common guillemot Uria aalge and razorbill Alca torda were combined because razorbill sample sizes were relatively low. Table 1 shows all correction factors applied for the analyses in the present paper. Correction factors were calculated by dividing the $300 \mathrm{~m}$ transect band by the estimated 'effective strip width' (in m; Buckland et al. 2001), as analysed by the software Distance 5.0. Abundances of flying birds were not corrected for distance as we assumed that, in contrast to swimming birds, all flying individuals within the area surveyed had been recorded completely.

Data on seabird abundance in the study area were analysed from the German Seabirds at Sea Database, Version 5.12, as of October 2008. In total, data for $407 \mathrm{~d}$ from July 1990 to May 2007 were available, summing to $4786.5 \mathrm{~km}^{2}$ of survey effort (Table 2). Although days were not sampled on an exact schedule every year, data effectively covered the different years and months over the whole study period, so possible biases due to unequal distribution of observation days should have been minimised. The unit for analysing bird data was the 'day'. For each day, and separately for all species, abundance values were obtained by: (1) summing the total number counted in the transect, (2) dividing this number by the survey effort $\left(\mathrm{km}^{2}\right)$, and (3) multiplying this value by the correction factor (see above). We thus obtained species-specific density values.

As the (variable) influence of abiotic parameters was much more of interest than the seasonal cycle, we chose 3 distinct 'seasons' and pooled all data within

Table 1. Correction factors calculated by distance sampling methods for birds on water for different seabird species at different sea states (Beaufort scale). See 'Materials and methods' for procedure. Correction factors in bold were used for analyses. Seasonal patterns of the species present in the study area are also given (see Fig. 2)

\begin{tabular}{|c|c|c|c|c|c|c|c|c|c|}
\hline Species & Taxon & $\begin{array}{c}\text { Seasonal } \\
\text { pattern }\end{array}$ & $0-1$ & 2 & 3 & $\begin{array}{c}\text { Sea state } \\
\quad 4-7\end{array}$ & $0-2$ & $3-7$ & $0-7$ \\
\hline Red-throated diver & Gavia stellata & $\mathrm{C}$ & - & - & - & - & 1.4 & 1.8 & 1.7 \\
\hline Northern gannet & Sula bassana & $\mathrm{a}$ & - & - & - & - & - & - & 1.5 \\
\hline Little gull & Hydrocoloeus minutus & $\mathrm{d}$ & - & - & - & - & 1.7 & 1.7 & 1.7 \\
\hline Black-headed gull & Larus ridibundus & a & 1.6 & 1.8 & 1.9 & 2.3 & - & - & 1.8 \\
\hline Common gull & Larus canus & $\mathrm{b}$ & 1.5 & 1.8 & 1.8 & 2.2 & - & - & 1.7 \\
\hline Lesser black-backed gull & Larus fuscus & $\mathrm{a}$ & 1.4 & 1.5 & 1.6 & 1.8 & - & - & 1.6 \\
\hline Herring gull & Larus argentatus & $\mathrm{b}$ & 1.5 & 1.6 & 1.7 & 2.2 & - & - & 1.7 \\
\hline Great black-backed gull & Larus marinus & $\mathrm{b}$ & - & - & - & - & 1.7 & 1.9 & 1.8 \\
\hline Black-legged kittiwake & Rissa tridactyla & $\mathrm{b}$ & 1.7 & 1.8 & 1.8 & 2.2 & - & - & 1.9 \\
\hline Sandwich tern & Sterna sandvicensis & a & - & - & - & - & 1.8 & 1.8 & 1.8 \\
\hline Common/Arctic tern & Sterna hirundo/paradisaea & $\mathrm{a}$ & - & - & - & - & 1.8 & 1.8 & 1.8 \\
\hline Common guillemot & Uria aalge & $\mathrm{b}$ & 1.6 & 2.0 & 2.0 & 2.2 & - & - & 2.1 \\
\hline Razorbill & Alca torda & $\mathrm{C}$ & 1.6 & 2.0 & 2.0 & 2.2 & - & - & 2.0 \\
\hline
\end{tabular}


Table 2. Number of observation days (upper value) and survey effort (lower value, in $\mathrm{km}^{2}$ ) per month and year in the study area from 1990 to 2007

\begin{tabular}{|c|c|c|c|c|c|c|c|c|c|c|c|c|c|}
\hline & Jan & Feb & Mar & Apr & May & Jun & Jul & Aug & Sep & Oct & Nov & Dec & Total \\
\hline 1990 & - & - & - & - & - & - & $\begin{array}{c}3 \\
24.4\end{array}$ & $\begin{array}{c}3 \\
34.5\end{array}$ & $\begin{array}{c}1 \\
19.4\end{array}$ & - & - & $\begin{array}{c}1 \\
17.1\end{array}$ & $\begin{array}{c}8 \\
95.4\end{array}$ \\
\hline 1991 & $\begin{array}{c}4 \\
43.9\end{array}$ & $\begin{array}{c}3 \\
35.0\end{array}$ & $\begin{array}{c}1 \\
08.3\end{array}$ & $\begin{array}{c}2 \\
19.1\end{array}$ & $\begin{array}{c}3 \\
34.0\end{array}$ & $\begin{array}{c}3 \\
47.6\end{array}$ & $\begin{array}{c}3 \\
30.8\end{array}$ & $\begin{array}{c}1 \\
21.7\end{array}$ & $\begin{array}{c}1 \\
05.9\end{array}$ & $\begin{array}{c}2 \\
17.6\end{array}$ & $\begin{array}{c}4 \\
37.1\end{array}$ & $\begin{array}{c}1 \\
08.9\end{array}$ & $\begin{array}{c}28 \\
309.9\end{array}$ \\
\hline 1992 & $\begin{array}{c}4 \\
44.8\end{array}$ & $\begin{array}{c}2 \\
15.4\end{array}$ & $\begin{array}{c}2 \\
21.0\end{array}$ & $\begin{array}{c}2 \\
16.4\end{array}$ & $\begin{array}{c}6 \\
67.4\end{array}$ & $\begin{array}{c}4 \\
38.8\end{array}$ & $\begin{array}{c}3 \\
32.7\end{array}$ & $\begin{array}{c}2 \\
25.3\end{array}$ & $\begin{array}{c}4 \\
37.5\end{array}$ & $\begin{array}{c}6 \\
52.0\end{array}$ & $\begin{array}{c}1 \\
06.8\end{array}$ & $\begin{array}{c}2 \\
26.6\end{array}$ & $\begin{array}{c}38 \\
384.7\end{array}$ \\
\hline 1993 & $\begin{array}{c}2 \\
23.5\end{array}$ & $\begin{array}{c}1 \\
08.3\end{array}$ & $\begin{array}{c}4 \\
43.4\end{array}$ & $\begin{array}{c}2 \\
29.1\end{array}$ & $\begin{array}{c}5 \\
62.6\end{array}$ & $\begin{array}{c}2 \\
16.4\end{array}$ & $\begin{array}{c}2 \\
32.6\end{array}$ & $\begin{array}{c}8 \\
93.3\end{array}$ & $\begin{array}{c}1 \\
08.4\end{array}$ & $\begin{array}{c}2 \\
28.2\end{array}$ & $\begin{array}{c}5 \\
55.1\end{array}$ & $\begin{array}{c}1 \\
9.0\end{array}$ & $\begin{array}{c}35 \\
409.9\end{array}$ \\
\hline 1994 & $\begin{array}{c}2 \\
16.3\end{array}$ & $\begin{array}{c}2 \\
15.4\end{array}$ & $\begin{array}{c}2 \\
21.3\end{array}$ & $\begin{array}{c}1 \\
09.5\end{array}$ & $\begin{array}{c}2 \\
19.4\end{array}$ & $\begin{array}{c}3 \\
29.1\end{array}$ & $\begin{array}{c}5 \\
80.3\end{array}$ & $\begin{array}{c}5 \\
49.0\end{array}$ & $\begin{array}{c}5 \\
56.3\end{array}$ & - & $\begin{array}{c}1 \\
9.0\end{array}$ & - & $\begin{array}{c}28 \\
305.6\end{array}$ \\
\hline 1995 & - & $\begin{array}{c}1 \\
09.2\end{array}$ & - & - & - & $\begin{array}{c}2 \\
24.3\end{array}$ & $\begin{array}{c}1 \\
08.3\end{array}$ & - & - & - & $\begin{array}{c}2 \\
14.4\end{array}$ & - & $\begin{array}{c}6 \\
56.2\end{array}$ \\
\hline 1996 & - & - & - & $\begin{array}{c}2 \\
16.6\end{array}$ & $\begin{array}{c}2 \\
20.3\end{array}$ & $\begin{array}{c}2 \\
21.4\end{array}$ & - & $\begin{array}{c}5 \\
52.9\end{array}$ & $\begin{array}{c}3 \\
38.2\end{array}$ & - & - & - & $\begin{array}{c}14 \\
149.4\end{array}$ \\
\hline 1997 & $\begin{array}{c}2 \\
16.3\end{array}$ & $\begin{array}{c}4 \\
29.7\end{array}$ & - & $\begin{array}{c}4 \\
29.2\end{array}$ & $\begin{array}{c}7 \\
75.9\end{array}$ & $\begin{array}{c}8 \\
71.8\end{array}$ & $\begin{array}{c}11 \\
135.7\end{array}$ & $\begin{array}{c}10 \\
112.6\end{array}$ & $\begin{array}{c}2 \\
19.8\end{array}$ & - & $\begin{array}{c}3 \\
25.1\end{array}$ & $\begin{array}{c}1 \\
08.5\end{array}$ & $\begin{array}{c}52 \\
524.6\end{array}$ \\
\hline 1998 & $\begin{array}{c}3 \\
25.5\end{array}$ & $\begin{array}{c}4 \\
32.3\end{array}$ & $\begin{array}{c}4 \\
38.7\end{array}$ & - & $\begin{array}{c}3 \\
66.5\end{array}$ & $\begin{array}{c}2 \\
19.5\end{array}$ & - & $\begin{array}{c}5 \\
51.2\end{array}$ & - & - & - & $\begin{array}{c}2 \\
17.9\end{array}$ & $\begin{array}{c}23 \\
251.6\end{array}$ \\
\hline 1999 & - & - & $\begin{array}{c}2 \\
16.0\end{array}$ & - & - & - & - & $\begin{array}{c}2 \\
92.7\end{array}$ & - & - & $\begin{array}{c}1 \\
08.9\end{array}$ & $\begin{array}{c}1 \\
08.6\end{array}$ & $\begin{array}{c}6 \\
126.2\end{array}$ \\
\hline 2000 & $\begin{array}{c}2 \\
16.8\end{array}$ & $\begin{array}{l}- \\
-\end{array}$ & $\begin{array}{c}3 \\
24.2\end{array}$ & $\begin{array}{c}2 \\
26.6\end{array}$ & $\begin{array}{c}2 \\
26.2\end{array}$ & $\begin{array}{c}4 \\
44.7\end{array}$ & $\begin{array}{c}1 \\
06.5\end{array}$ & $\begin{array}{c}2 \\
17.0\end{array}$ & - & $\begin{array}{c}1 \\
07.8\end{array}$ & $\begin{array}{c}2 \\
16.3\end{array}$ & $\begin{array}{c}3 \\
25.0\end{array}$ & $\begin{array}{c}22 \\
211.1\end{array}$ \\
\hline 2001 & $\begin{array}{c}1 \\
08.5\end{array}$ & - & $\begin{array}{c}2 \\
20.7\end{array}$ & $\begin{array}{c}4 \\
42.2\end{array}$ & $\begin{array}{c}2 \\
61.8\end{array}$ & $\begin{array}{c}3 \\
25.4\end{array}$ & $\begin{array}{c}3 \\
32.7\end{array}$ & - & - & - & - & $\begin{array}{c}3 \\
27.9\end{array}$ & $\begin{array}{c}18 \\
219.2\end{array}$ \\
\hline 2002 & - & - & - & $\begin{array}{c}3 \\
27.5\end{array}$ & $\begin{array}{c}5 \\
51.6\end{array}$ & $\begin{array}{c}5 \\
42.9\end{array}$ & $\begin{array}{c}3 \\
26.0\end{array}$ & $\begin{array}{c}2 \\
16.6\end{array}$ & $\begin{array}{c}3 \\
26.6\end{array}$ & $\begin{array}{c}2 \\
20.6\end{array}$ & - & - & $\begin{array}{c}23 \\
211.8\end{array}$ \\
\hline 2003 & - & $\begin{array}{c}1 \\
11.0\end{array}$ & $\begin{array}{c}3 \\
34.5\end{array}$ & $\begin{array}{c}4 \\
79.4\end{array}$ & $\begin{array}{c}1 \\
07.7\end{array}$ & $\begin{array}{c}3 \\
26.0\end{array}$ & $\begin{array}{c}1 \\
05.9\end{array}$ & $\begin{array}{c}11 \\
194.4\end{array}$ & - & - & - & $\begin{array}{c}1 \\
8.0\end{array}$ & $\begin{array}{c}25 \\
366.9\end{array}$ \\
\hline 2004 & - & - & - & $\begin{array}{c}1 \\
12.2\end{array}$ & - & $\begin{array}{c}2 \\
23.7\end{array}$ & $\begin{array}{c}1 \\
19.5\end{array}$ & $\begin{array}{c}3 \\
44.7\end{array}$ & $\begin{array}{c}2 \\
25.3\end{array}$ & - & $\begin{array}{c}2 \\
36.2\end{array}$ & - & $\begin{array}{c}11 \\
161.6\end{array}$ \\
\hline 2005 & - & - & $\begin{array}{c}1 \\
07.6\end{array}$ & $\begin{array}{c}3 \\
29.2\end{array}$ & $\begin{array}{c}7 \\
93.1\end{array}$ & $\begin{array}{c}7 \\
109.5\end{array}$ & $\begin{array}{c}3 \\
50.0\end{array}$ & $\begin{array}{c}5 \\
90.5\end{array}$ & $\begin{array}{c}3 \\
50.7\end{array}$ & $\begin{array}{c}2 \\
38.4\end{array}$ & $\begin{array}{c}1 \\
08.5\end{array}$ & $\begin{array}{c}2 \\
18.3\end{array}$ & $\begin{array}{c}34 \\
495.8\end{array}$ \\
\hline 2006 & $\begin{array}{c}1 \\
08.8\end{array}$ & $\begin{array}{c}1 \\
14.8\end{array}$ & $\begin{array}{c}2 \\
17.1\end{array}$ & $\begin{array}{c}2 \\
28.7\end{array}$ & $\begin{array}{c}3 \\
38.3\end{array}$ & $\begin{array}{c}5 \\
75.0\end{array}$ & $\begin{array}{c}3 \\
52.8\end{array}$ & $\begin{array}{c}4 \\
54.0\end{array}$ & $\begin{array}{c}2 \\
39.6\end{array}$ & $\begin{array}{c}2 \\
15.2\end{array}$ & $\begin{array}{c}1 \\
09.1\end{array}$ & $\begin{array}{c}1 \\
09.8\end{array}$ & $\begin{array}{c}27 \\
363.2\end{array}$ \\
\hline 2007 & $\begin{array}{c}1 \\
07.1\end{array}$ & $\begin{array}{c}1 \\
15.7\end{array}$ & $\begin{array}{c}2 \\
31.3\end{array}$ & $\begin{array}{c}3 \\
49.5\end{array}$ & $\begin{array}{c}2 \\
39.8\end{array}$ & - & - & - & $\begin{array}{l}- \\
-\end{array}$ & - & - & - & $\begin{array}{c}9 \\
143.4\end{array}$ \\
\hline Total & $\begin{array}{c}22 \\
211.5\end{array}$ & $\begin{array}{c}20 \\
186.8\end{array}$ & $\begin{array}{c}28 \\
284.1\end{array}$ & $\begin{array}{c}35 \\
415.2\end{array}$ & $\begin{array}{c}50 \\
664.6\end{array}$ & $\begin{array}{c}55 \\
616.1\end{array}$ & $\begin{array}{c}43 \\
538.2\end{array}$ & $\begin{array}{c}68 \\
950.4\end{array}$ & $\begin{array}{c}27 \\
327.7\end{array}$ & $\begin{array}{c}17 \\
179.8\end{array}$ & $\begin{array}{c}23 \\
226.5\end{array}$ & $\begin{array}{c}19 \\
185.6\end{array}$ & $\begin{array}{c}407 \\
4786.5\end{array}$ \\
\hline
\end{tabular}

these. Seasons were defined to match the species presence in the study area (for species-specific seasons see Garthe et al. 2007). The periods of the year not covered by our analyses were eliminated, due either to insufficent sample sizes (i.e. the number of days at sea with sufficient coverage, e.g. spring) or because these were transient months associated with different 'seasons' for the different species (e.g. the second half of July partly represents the breeding period, and partly, autumn migration).

For each season, we included in the analysis those species that were present on at least $15 \%$ of the observation days. The only exceptions were common eider
Somateria mollissima and common scoter Melanitta nigra, which were excluded from the analysis in winter, as the study area is located clearly outside their foraging and resting areas and recordings were only from migrating birds. For the seasonal analyses, the species analysed in detail comprised 39\% (winter), 94\% (autumn migration) and $94 \%$ (reproductive period) of overall seabird abundance. Ignoring the 2 sea duck species mentioned above, the values increased to $96 \%$ (winter), 98\% (autumn migration) and 99\% (reproductive period). Divers (i.e. loons Gavia spp.) were defined as red-throated divers Gavia stellata, because $93 \%$ of all divers identified to species and registered in the 
transect were of that species (69\% of all divers were identified to species; $\mathrm{n}=363$ individuals). Common terns Sterna hirundo and Arctic terns Sterna paradisaea were pooled as commic terns. A total of $57 \%$ of all commic terns was identified to species ( $\mathrm{n}=1202$ individuals). Although common terns were more numerous and made up $83 \%$ of all commic terns registered in the transect and identified to species, a relatively high percentage of non-identified individuals occurred on some observation days (in contrast to the case of the divers), so that simple species allocation was not regarded as adequate. In all other cases, proportions of unidentified birds were very small and therefore negligible $(0.7 \%$ of common guillemot and razorbill and $0.03 \%$ of large gulls). Scientific names of the bird species follow Bauer et al. (2005).

Environmental data. In spite of having a large set of hydrographic and meteorological parameters, only those that were considered meaningful from a seabird biology and marine ecology point of view (Table 3) were selected. Thus, e.g., precipitation and visibility were neglected because, to the best of our knowledge, they do not generally affect seabird abundance directly. Also, strongly correlated factors were avoided, e.g. multiple measurements of the same or a similar parameter on a specific day. The variables finally selected for analysis were only weakly correlated, with a maximum Pearson correlation coefficient of 0.4 (Table 4). Furthermore, it was considered that the temporal resolution (e.g. 1 measurement per day) of some environmental parameters (e.g. air pressure) might not be appropriate, as they are fast changing. In such cases, ratios or means were calculated (see below).

Two hydrographic parameters, sea surface temperature (SST) and sea surface salinity (SSS; Table 3), were analysed from the Helgoland Roads time series (Franke et al. 2004, Wiltshire \& Manly 2004) provided by the Alfred-Wegener Institute for Polar and Marine Research. These parameters were measured from a boat at a fixed place near the island of Helgoland once a day on working days. We interpolated values for days not sampled (weekends and public holidays). Helgo-

Table 3. Environmental parameters and their time scales as used in this study. The measurement frequency for each parameter is one value per day. SST: sea surface temperature; SSS: sea surface salinity; CET: Central European Time. $\Delta$ T: Temperature difference

\begin{tabular}{|c|c|c|}
\hline Parameter & Unit & Explanation \\
\hline SST anomaly & ${ }^{\circ} \mathrm{C}$ & $\begin{array}{l}\text { Deviance of the SST value on a specific date (e.g. } 1 \text { April 2000) from its long-term } \\
\text { mean for that date (e.g. mean for } 1 \text { April from } 1990 \text { to 2007) }\end{array}$ \\
\hline SSS anomaly & $\mathrm{psu}$ & $\begin{array}{l}\text { Deviance of the SSS value on a specific date (e.g. } 1 \text { April 2000) from its long-term } \\
\text { mean for that date (e.g. mean for } 1 \text { April from } 1990 \text { to 2007) }\end{array}$ \\
\hline Absolute air pressure & $\mathrm{hPa}$ & Mean of measurements from 07:00, 14:00 and 21:00 h CET on the observation day \\
\hline Preceding air pressure change & $\mathrm{hPa}$ & $\begin{array}{l}\text { Difference between 07:00 h CET on the day before the observation day and } \\
07: 00 \mathrm{~h} \text { CET on the observation day }\end{array}$ \\
\hline Concurrent air pressure change & $\mathrm{hPa}$ & Difference between 07:00 and 21:00 h CET on the observation day \\
\hline Wind field & - & $\begin{array}{l}\text { Combination of wind direction and wind speed on the observation day For wind } \\
\text { directions (measured at 07:00 h CET) from the sea (SW, W, NW), the Beaufort- } \\
\text { scaled wind speeds (measured at 07:00 h CET) were taken as positive values, } \\
\text { while for wind directions from land (N, NE, E, SE, S), the Beaufort-scaled wind } \\
\text { speeds were multiplied by -1 }\end{array}$ \\
\hline$\Delta \mathrm{T}$ : water-atmosphere & ${ }^{\circ} \mathrm{C}$ & $\begin{array}{l}\text { Difference between the SST value and the mean atmospheric temperature } \\
\text { value on the observation day }\end{array}$ \\
\hline
\end{tabular}

Table 4. Cross correlations between the environmental parameters used for analysis. Correlation coefficients shown are based on Pearson correlations for the whole data set (407 observation days; see Table 1). SST: sea surface temperature; SSS: sea surface salinity. $\Delta \mathrm{T}$ : Temperature difference

\begin{tabular}{|c|c|c|c|c|c|c|c|}
\hline & $\begin{array}{c}\text { SST } \\
\text { anomaly }\end{array}$ & $\begin{array}{c}\text { SSS } \\
\text { anomaly }\end{array}$ & $\begin{array}{l}\text { Absolute } \\
\text { air } \\
\text { pressure }\end{array}$ & $\begin{array}{l}\text { Preceding } \\
\text { air pressure } \\
\text { change }\end{array}$ & $\begin{array}{c}\text { Concurrent } \\
\text { air pressure } \\
\text { change }\end{array}$ & $\begin{array}{l}\text { Wind } \\
\text { field }\end{array}$ & $\begin{array}{c}\Delta \mathrm{T}: \\
\text { water- } \\
\text { atmosphere }\end{array}$ \\
\hline SST anomaly & _- & & & & & & \\
\hline SSS anomaly & -0.137 & - & & & & & \\
\hline Absolute air pressure & 0.028 & 0.025 & - & & & & \\
\hline Preceding air pressure change & -0.073 & 0.118 & 0.404 & - & & & \\
\hline Concurrent air pressure change & -0.055 & 0.083 & -0.117 & 0.147 & _ & & \\
\hline Wind field & 0.005 & 0.055 & 0.024 & 0.130 & 0.120 & _- & \\
\hline$\Delta \mathrm{T}$ : water-atmosphere & -0.098 & -0.008 & 0.061 & 0.042 & 0.104 & 0.020 & - \\
\hline
\end{tabular}


land Roads is located only $6.5 \mathrm{~km}$ west of the study area. As we were not interested in the annual cycle of these parameters but rather in their deviance from the means, we calculated daily means for both, and used 'SST anomaly' and 'SSS anomaly' as the deviations from the long-term mean on the respective day. SST anomalies should indicate warmer or colder years; SSS anomalies should indicate influence of Continental Coast Water Mass (if SSS values are lower than on average) or Central North Sea Water Mass (if SSS values are higher than on average; see also Loewe et al. 2006). These different causes for changes in SST and SSS are also supported by the fact that SST and SSS were not correlated $(\mathrm{r}=-0.003, \mathrm{df}=4187, \mathrm{p}=0.846$, Pearson correlation; data from 1 January 1990 to 31 May 2007).

Meteorological data were obtained from the German Weather Service (DWD). They were selected to reflect important atmospheric parameters possibly influencing seabird behaviour, e.g. when foraging and migrating (all times are given according to Central European Time; Table 3): (1) absolute air pressure (means of measurements from 07:00, 14:00 and 21:00 $\mathrm{h}$ on the observation day), (2) preceding air pressure change (from 07:00 $\mathrm{h}$ on the day before the observation day to $07: 00 \mathrm{~h}$ on the observation day), (3) concurrent air pressure change (from 07:00 to 21:00 h on the observation day), (4) wind field (see below) and (5) the temperature difference between SST and the atmospheric temperature on the observation day. The last parameter was based on observations by Haney \& Lee (1994), who suggested that air-sea heat flux and ocean wind fields may have a strong influence on offshore dispersal of gulls by facilitating energy-efficient flying under certain conditions. For the wind field, the selected variable includes a quantitative combination of direction and speed, scaled to highlight an onshore/offshore axis. For wind directions (measured at 07:00 h) from the sea (SW, W, NW), the Beaufort-scaled wind speeds (measured at 07:00 h) were taken as positive values, while for wind directions from land (N, NE, E, SE, S), the Beaufort-scaled wind speeds were multiplied by -1 .

Statistical analysis. The comparison of bird abundance and abiotic parameters was done on a daily basis; bird abundance was obtained from our own data set on seabirds at sea (see 'Bird data' above), and abiotic parameters were gleaned from archived materials (see 'Environmental data' above and Table 3). The relationships between bird abundance and abiotic parameters were investigated using generalised additive models (GAMs; Hastie \& Tibshirani 1990, Wood 2006). Influences of the hydrographic and meteorological parameters on seabird abundance in the study area were tested separately for each species and season. GAMs with quasi-Poisson error distribution were performed using the MGCV package (Wood 2008) of the open source software package R 2.8.1 (R Development Core Team 2008). As the data set was based on counts, the Poisson function should usually form the basis of the analysis (Zuur et al. 2007). However, to prevent overdispersion, an underlying quasi-Poisson function was selected in the model frame. Models were selected using backward selection and exclusion of non-significant predictor variables (applying the ANOVA function with F-statistics). To avoid over-fitting of models (Meynard \& Quinn 2007), only seasons with an adequate sample size were used ( $\geq 80$ observation days), rare species were disregarded (see 'Bird data' above) and the degrees of freedom for curve smoothing were restricted to 4. Models were validated applying 10-fold crossvalidations, which were repeated 10 times. We calculated the root mean-squared error of prediction (RMSEP) and the correlation between observed values and the values predicted during the cross-validation procedure $\left(\mathrm{r}^{2}\right)$ to obtain measures of model performance.

As the wind field is considered a central element responsible for the distribution of water masses and also influencing bird flight behaviour, we investigated whether onshore wind versus offshore wind conditions may lead to differences in the quantitative composition of the seabird community. Analysis was performed for winter only, as this is the period during which the least migratory movements are expected and when no birds commute between colonies and feeding grounds. We tested whether the (daily) species abundance values differed between $52 \mathrm{~d}$ with offshore conditions (wind from land towards the sea) and $32 \mathrm{~d}$ with onshore conditions. We conducted a Monte Carlo permutation test with 1000 permutations, based on a detrended correspondence analysis (DCA). A dummy variable wind (0 for onshore wind, 1 for offshore wind) was introduced and tested for significance to the quantitative species data. This test was undertaken using the package 'vegan' (Oksanen et al. 2008) in R. Significance levels were set to 0.05 for all analyses.

\section{RESULTS}

\section{Seasonality}

The species in the study area exhibited different seasonal patterns. While some species were present yearround, others occurred only at certain periods. Principally, all species can be divided into 4 groups as exemplified in Fig. 2: (a) species that occur from spring to autumn and breed on islands or along the coast near the study area, but leave the study area in winter, e.g. Larus fuscus; (b) species that occur year-round and breed nearby, e.g. L. canus; (c) species that occur from 

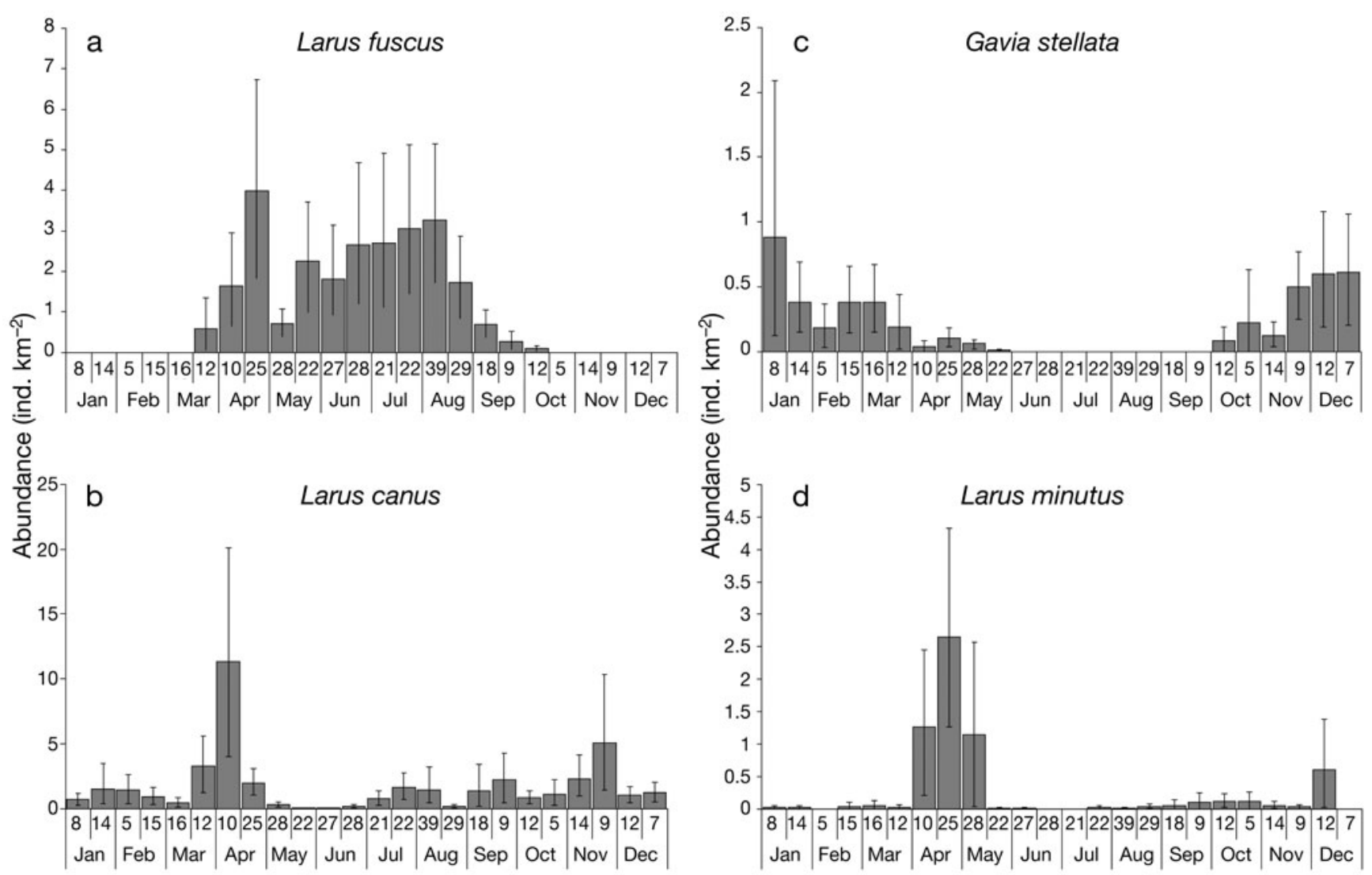

Month and sample size

Fig. 2. Abundance patterns of 4 seabird species over the annual cycle. Each month is split into 2 halves, with the number of days from 1990 to 2007 as sample size indicated below the $x$-axis. Means and 95\% confidence intervals are based on bootstrapping the original values 10000 times: (a) lesser black-backed gull Larus fuscus, (b) common gull L. canus, (c) red-throated diver Gavia stellata, (d) little gull L. minutus

autumn to spring, including the winter period, but leave the area for breeding, e.g. Gavia stellata; and (d) species that predominantly occur during the autumn and spring migration periods and have a clear bimodal distribution, e.g. L. minutus.

\section{Influence of hydrographic and meteorological parameters on seabird abundance}

All 5 meteorological and 2 hydrographic parameters significantly influenced the abundance of seabird species in the study area in the southeastern North Sea, though to a different degree (Table 5). Except for the common guillemot during the reproductive period, the GAMs found at least 1 abiotic parameter explaining considerable variance in species abundance. Overall, the 2 hydrographic parameters were significant in $54 \%$ of all species/season combinations, while the 5 atmospheric parameters were significant in $44 \%$ of these combinations. The single factors that most often had a significant influence in the single models were wind field, SST anomaly, SSS anomaly and preceding air pressure change (Table 5).

Two typical patterns are explained in more detail. Species responded differently to the wind field, with species such as the common gull Larus canus being significantly less abundant during onshore wind conditions, while the opposite was true for the black-legged kittiwake Rissa tridactyla (Fig. 3). Especially during autumn migration, but also during the 2 other periods, species were often significantly more abundant when air pressure was high and/or increased, as shown for the black-headed gull L. ridibundus (Fig. 4). These responses were apparent in several species.

For all models the results of the cross-validation were characterized with a low $\mathrm{r}^{2}(<0.1)$ and a large RMSEP.

\section{Seabird community and wind field}

The quantitative composition of the seabird community in the HELBOX area differed significantly between onshore wind and offshore wind conditions in winter 


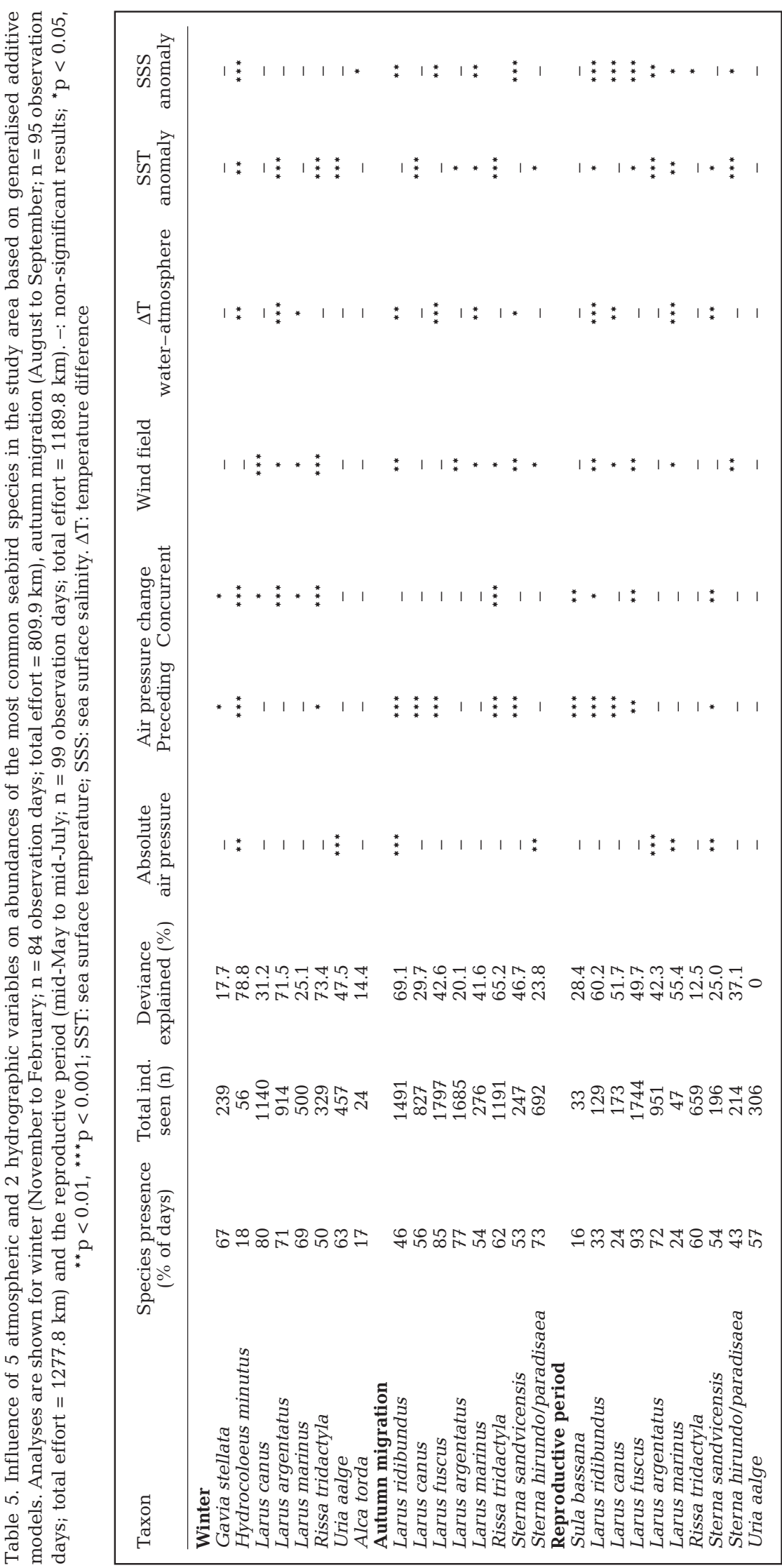

$\left(r^{2}=0.27, n=84 d, p=0.033\right.$, detrended correspondence analysis with Monte Carlo permutation). During onshore wind situations, common guillemots Uria aalge and black-legged kittiwakes constituted much higher percentages than during offshore wind situations, while common gulls and herring gulls Larus argentatus occurred in higher percentages during offshore wind situations (Fig. 5).

\section{DISCUSSION}

\section{Influence of season and abiotic parameters}

The different seabird species exhibit different seasonal patterns in the southern North Sea. Interestingly, despite substantial changes in abundances, the nature of the relations between bird abundances and abiotic parameters did not vary much between seasons. However, the highest deviances explained by the GAMs were only achieved in winter and during autumn migration. This substantiates that breeding birds are restricted in their spatial distribution, as they have to commute regularly to their breeding colonies for territorial and nest defence, incubation and chick provisioning. Thus, they are bound to stay within their foraging range, thereby possibly masking 'ideal' habitat relationships (Garthe 1997, Markones 2007).

The seabird assemblage in the study area consists mostly of highly mobile and frequently flying species. It can consequently be expected that, on the one hand, hydrographic parameters are relevant for the birds, determining the foraging habitats and options, and, on the other hand, atmospheric parameters, influencing flight conditions during foraging and migration. Flying in adverse conditions is energetically expensive, and birds may avoid extensive movements under such conditions (Haney \& Lee 1994). The significant influence of air pressure was revealed in several species. High air pressure per se generally coincides with 'good weather', i.e. clear skies and good visibility, which facilitates orientation, whereas low pressure 

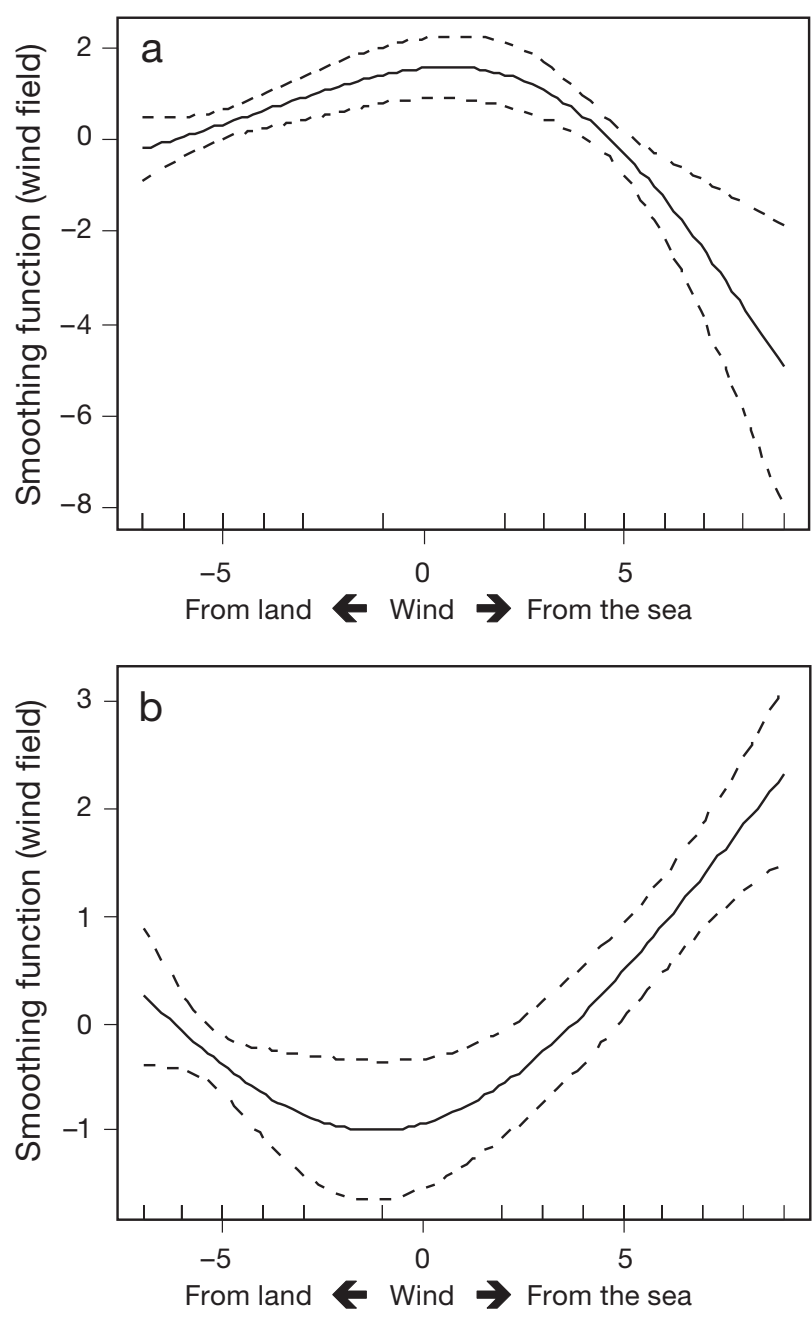

Fig. 3. Generalised additive model (GAM) smoothing curve fitted to partial effects of explanatory variables on abundance of (a) common gulls Larus canus and (b) black-legged kittiwakes Rissa tridactyla in winter. Density is represented as a function of the variable 'wind field'. Dashed lines show $95 \%$ confidence intervals around the main effects. Common gull: $F=6.368$, $\mathrm{p}<0.001$; black-legged kittiwake: $F=18.572, \mathrm{p}<0.0001$

is associated with precipitation and poor visibility. Periods of high pressure are thus often characterized by high migration intensities, though some species are observed migrating beneath, above, or even in clouds (Richardson 1990). Others migrate only when all orientation cues are available (Nilsson et al. 2006). This may hold true not only for birds on migration, but also for offshore foraging flights of coastal birds, such as gulls and terns, during the breeding season. Our variable 'wind field' is a particularly important factor for 2 reasons. First, wind speed and wind direction are known to influence or determine when and where birds are able to fly (Woodcock 1940, Manikowski 1971, Furness \& Bryant 1996). Although we did not sample many days with wind speeds $>7$ on the Beaufort scale (i.e.
$>17 \mathrm{~m} \mathrm{~s}^{-1}$ ), even wind speeds of 10 to $15 \mathrm{~m} \mathrm{~s}^{-1}$ may have strong effects on field metabolic rates (Gabrielsen et al. 1987) and flight performance (Spear \& Ainley 1997). Strong winds also reduce foraging options (Dunn 1973, Finney et al. 1999). In the southeastern North Sea strong winds reduce commercial fishing activity and thus the availability of discards for scavenging seabirds and, for gulls, are correlated with high proportions of resting (Markones et al. 2008). Second, the wind regime steers the distribution of the water masses in the German Bight and is thus a proxy for maritime versus coastal/freshwater conditions. Consequently, this factor significantly changed the composition of the community in the study area, with pelagic species, such as common guillemot and black-legged kittiwake, dominating during sea wind conditions, while coastal species, such as common and herring gull, dominated during land wind conditions. It is somewhat surprising that the 2 hydrographic parameters were not significant in more models. A possible reason is that the Helgoland Roads station is only partly a good indicator for the study area; unfortunately, no other stations or data sets were available throughout our time series. Sea surface salinity may also be an important indicator of fronts (Skov \& Prins 2001, Markones 2007), but frontal occurrence and related bird distribution are much smaller scale processes in space and time and thus were not detectable by our analysis.

Responses to the environmental parameters varied between species, but also between seasons within the same species. There was a tendency for the diving species (divers, auks) to respond to fewer atmospheric parameters than the other species that forage in flight. This would make sense as flying is much more vulnerable to adverse weather conditions than diving. On the other hand, most species showed stronger responses to atmospheric conditions during the main migration period from August through September than, e.g., during the breeding period (see the discussion above).

\section{Methodology}

There are constraints when studying seabird distributions at sea from ships in relation to environmental conditions, as adverse conditions affect the ability to detect and census certain species. We tried to circumvent this problem by only using count data when visibility was good enough for overlooking the transect area and substantially beyond, and when other weather conditions such as wind, rain and spray were not affecting the counts. We calculated sea-statedependent correction factors to adjust counts for birds overlooked in the outer transect area. However, Ron- 

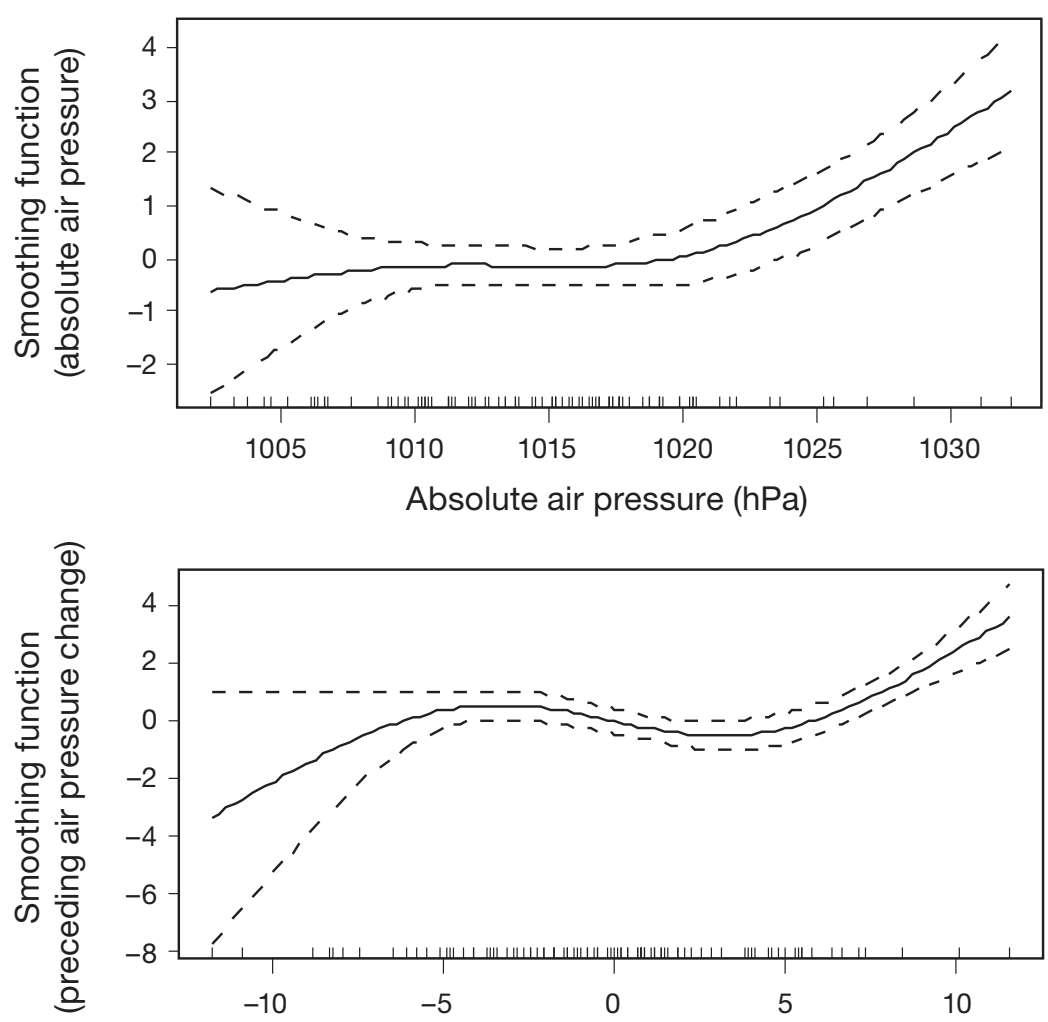

Air pressure change from 07:00 $\mathrm{h}$ on the previous day to $07: 00 \mathrm{~h}$ on observation day $(\mathrm{hPa})$

Fig. 4. Generalised additive model (GAM) smoothing curve fitted to partial effects of explanatory variables on abundance of black-headed gulls Larus ridibundus during autumn migration. Density is represented as a function of the variables (a) 'absolute air pressure' and (b) 'preceding air pressure change'. Dashed lines show 95\% confidence intervals around the main effects. Absolute air pressure: $F=14.702, \mathrm{p}<0.0001$; preceding air pressure change: $F=18.309$, $\mathrm{p}<0.0001$

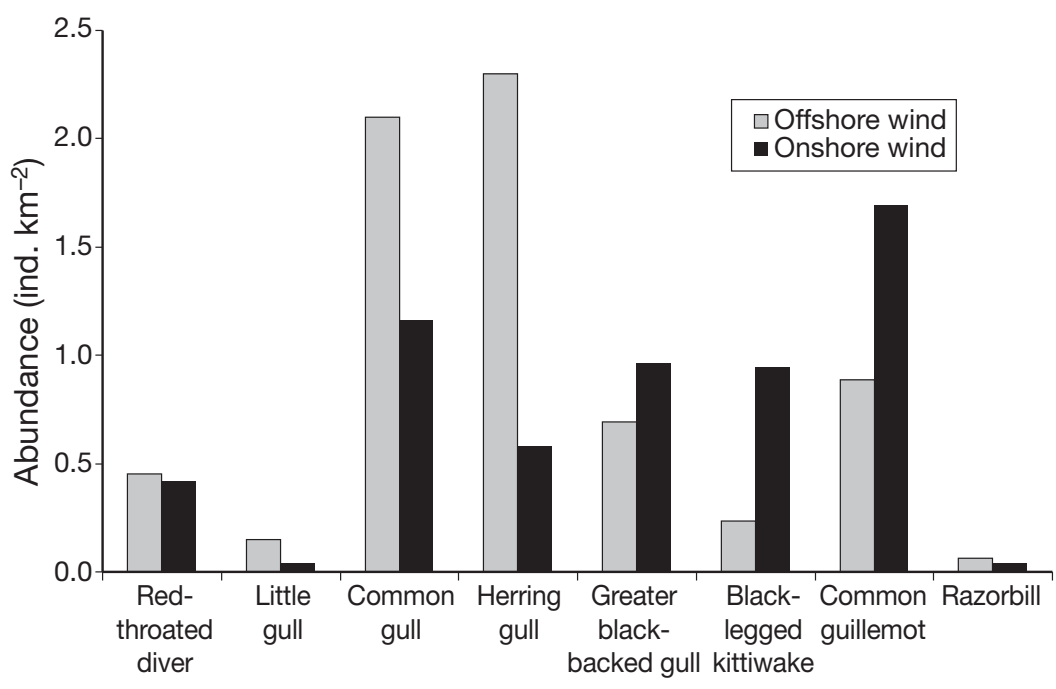

Fig. 5. Composition of the seabird community in winter during offshore and onshore wind conditions. For taxonomic names, see Table 1 coni \& Burger (2009) point out that the basic assumption for this methodology, seeing all birds in front of the boat near the transect line, may be violated in some species that are difficult to detect. Fortunately, no such species (e.g. small auks) occurred in considerable quantities in our study area. Hyrenbach et al. (2007) highlight the need to test survey techniques for different survey platforms, as the latter provide different advantages and disadvantages for detecting birds. The authors also showed that cloud cover and sea state may affect census properties. We accounted for the latter effect by calculating different correction factors for different sea states.

This analysis focused on the influence of major hydrographic and atmospheric parameters on the abundance of seabird species during 3 different seasons. Such comprehensive analyses are associated with advantages and disadvantages. To establish a baseline of the influence of abiotic conditions on seabird abundance, it is advantageous to investigate the influence of these factors on all species during different periods of the annual cycle. However, sample sizes could never be large enough to test the whole suite of possible factors, interacting effects and their combinations. Thus, a pre-selection of pertinent parameters is unavoidable, in our analyses as well as in others.

Some important parameters were not included in this analysis, although they are known to affect seabird abundance and distribution patterns. Fish trawler abundance data were not available at the required temporal and spatial resolution. Previous analyses have shown that trawler distribution may influence the distribution of some seabird species feeding on discards (Camphuysen et al. 1995, Garthe 1997), but more complex analyses revealed that this factor is not related in a straightforward manner to seabird abundance and that it interacts strongly with various other factors (Markones et al. 2008). The influence of tides (Becker et al. 1993, Schwemmer \& Garthe 2008) and the time of day (Burger 1983, Markones et al. 2008) 
were excluded, as they are also very complex. Furthermore, in an 18 yr data set, trends in numbers over time do occur. Although such trends were detected for the German Bight (Garthe \& Schwemmer 2005), they did not appear to be strong enough to affect our analyses. Generally, results of GAMs have to be treated with care, as indicated by high prediction errors and low correlation between observed values and values predicted during cross-validation procedures. Thus, they may be sufficient to explain the factors causing the observed variance in seabird abundance, but not to enable predictions. Further species-specific analyses would be required focussing on certain parameters in more detail.

\section{Implications for monitoring programmes, marine protected area delineation and climate change predictions}

The findings from our analyses have some strong implications for other issues. First, seabird at sea monitoring programmes need to take different weather scenarios into account to obtain the full picture, not only patterns from high-pressure, low-wind scenarios. This is particularly relevant for aerial surveys that can only be conducted when the sea state is very low, as birds otherwise cannot be distinguished from wave crests (Camphuysen et al. 2004). Such conditions often occur during passages of (ridges of) high pressure systems, often in combination with easterly winds, that in turn enhance the abundance of coastal species, such as black-headed gulls and common gulls, and may also trigger migration (Hüppop et al. 2006). Furthermore, it needs to be considered how representative such surveys are, especially for certain species that respond strongly to atmospheric parameters.

Similar implications hold true for the identification and delineation of marine protected areas, especially those designated for seabirds that are not related to fixed bottom structures but to hydrographic features such as water masses and fronts. The preferred habitats of such species vary in location and extent with changing hydrographic and meteorological parameters (Markones 2007); thus, habitat models need to be incorporated into recommendations for locations of protected areas (Louzao et al. 2006). Protected areas for seabirds in the Exclusive Economic Zone of Germany have recently been designated, as demanded by the EU Birds Directive (Garthe 2006), but such approaches assume that the distribution of birds does not change over time. Changes in seabird abundance and distribution may, however, occur as a consequence of substantial changes in the North Sea ecosystem (Beaugrand 2004, Edwards \& Richardson 2004).
Finally, statistical models such as those developed in the present paper will enable predictions, for example on the consequences of climate change. Scenarios will consider future changes in environmental parameters, such as wind fields, pressure systems and SST (Christensen et al. 2007). From the data shown here we can expect substantial effects of future climatic changes on the composition of the seabird community in the southern North Sea, due to the link between relevant environmental parameters and seabird distribution. This prediction is further supported by the fact that climatic and hydrographic parameters are known to significantly affect seabird demography (Sandvik et al. 2008).

Acknowledgements. This analysis was conducted as part of the project 'Habitatwahl der Seevögel in der deutschen Nordund Ostsee als Grundlage zur Bewertung von Eingriffen' (FKZ 0327627), financed by the German Federal Environmental Ministry (BMU). The ship cruises providing the basic data set were mainly funded by projects from the Federal Environmental Ministry (BMU), the Federal Agency for Nature Conservation (BfN), the National Park Authority Schleswig-Holstein (NPA), the Agency for Ecology Niedersachsen (NLÖ) and the Freunde und Förderer der Inselstation der Vogelwarte Helgoland, as well as considerable voluntary work. Numerous observers were active over the 18 yr of data collection. The Alfred-Wegener Institute for Polar and Marine Research (AWI) and the German Weather Service (DWD) provided the abiotic data.

\section{LITERATURE CITED}

Bauer HG, Bezzel E, Fiedler W (2005) Das Kompendium der Vögel Mitteleuropas. Band 1: Nonpasseriformes - Nichtsperlingsvögel. Aula Verlag, Wiebelsheim

Beaugrand G (2004) The North Sea regime shift: evidence, causes, mechanisms and consequences. Prog Oceanogr 60: 245-262

Becker GA, Fiúza AFG, James ID (1983) Water mass analysis in the German Bight during MARSEN, phase I. J Geophys Res 88:9865-9870

Becker PH, Frank D, Sudmann SR (1993) Temporal and spatial pattern of common tern (Sterna hirundo) foraging in the Wadden Sea. Oecologia 93:389-393

Buckland ST, Anderson DR, Burnham KP, Laake JL, Borchers DL, Thomas L (2001) Introduction to distance sampling: estimating abundance in biological populations. TJ International, Padstow

Burger J (1983) Jamaica Bay studies. III. Abiotic determinants of distribution and abundance of gulls (Larus). Estuar Coast Shelf Sci 16:191-216

Camphuysen CJ, Garthe S (2004) Recording foraging seabirds at sea. Standardised recording and coding of foraging behaviour and multi-species foraging associations. Atlantic Seabirds 6:1-32

Camphuysen CJ, Calvo B, Durinck J, Ensor K and others (1995) Consumption of discards by seabirds in the North Sea. Final report EC DG XIV research contract BIOECO/ 93/10. NIOZ-Rapport 1995-5, Netherlands Institute for Sea Research, Texel 
Camphuysen CJ, Fox AD, Leopold MF, Petersen IK (2004) Towards standardized seabirds at sea census techniques in connection with environmental impact assessments for offshore wind farms in the UK. Final report COWRIEBAM-02-2002. Royal Netherlands Institute for Sea Research, Texel

Christensen JH, Hewitson B, Busuioc A, Chen A and others (2007) Regional climate projections. In: Solomon S, Qin D, Manning M, Chen Z and others (eds) Climate change 2007: the physical science basis. Contribution of Working Group I to the 4th assessment report of the Intergovernmental Panel on Climate Change. Cambridge University Press, Cambridge

Dietrich G, Kalle K, Krauss W, Siedler G (1975) Allgemeine Meereskunde. Eine Einführung in die Ozeanographie (3. Aufl.). Gebrüder Borntraeger, Berlin

Duffy DC (1983) The effect of wave height on bird counts at sea. Cormorant 11:21-24

- Dunn EK (1973) Changes in fishing ability of terns associated with windspeed and sea surface conditions. Nature 244: 520-521

Edwards M, Richardson AJ (2004) Impact of climate change on marine pelagic phenology and trophic mismatch. Nature 430:881-884

Elkins N (1988) Weather and bird behaviour. Poyser, Calton

Finney SK, Wanless S, Harris MP (1999) The effect of weather conditions on the feeding behaviour of a diving bird, the common guillemot Uria aalge. J Avian Biol 30:23-30

Franke HD, Buchholz F, Wiltshire K (2004) Ecological longterm research at Helgoland (German Bight, North Sea): retrospect and prospect-an introduction. Helgol Mar Res 58:223-229

Furness RW, Bryant DM (1996) Effect of wind on field metabolic rates of breeding northern fulmars. Ecology 77: $1181-1188$

Gabrielsen GW, Mehlum F, Nagy KA (1987) Daily energy expenditure and energy utilization of free-ranging blacklegged kittiwakes. Condor 89:126-132

Garthe S (1997) Influence of hydrography, fishing activity and colony location on summer seabird distribution in the south-eastern North Sea. ICES J Mar Sci 54:566-577

Garthe S (2006) Identification of areas of seabird concentrations in the German North Sea and Baltic Sea using aerial and ship-based surveys. In: von Nordheim $\mathrm{H}$, Boedeker D, Krause JC (eds) Progress in marine conservation in Europe: Natura 2000 sites in German offshore waters. Springer, Berlin, p 225-238

Garthe S, Schwemmer P (2005) Seabirds at sea-Untersuchungen in den deutschen Meeresgebieten. Vogelwelt 126:67-74

Garthe S, Sonntag N, Schwemmer P, Dierschke V (2007) Estimation of seabird numbers in the German North Sea throughout the annual cycle and their biogeographic importance. Vogelwelt 128:163-178

Haney JC, Lee DS (1994) Air-sea heat flux, ocean wind fields, and offshore dispersal of gulls. Auk 111:427-440

Hastie T, Tibshirani R (1990) Generalised additive models. Chapman and Hall, London

Heinemann D (1981) A range finder for pelagic bird censusing. J Wildl Manage 45:489-493

Hunt GL Jr (1990) The pelagic distribution of marine birds in a heterogeneous environment. Polar Res 8:43-54

Hunt GL Jr, Schneider DC (1987) Scale-dependent processes in the physical and biological environment of marine birds. In: Croxall JP (ed) Seabirds: feeding ecology and role in marine ecosystems. Cambridge University Press, Cambridge, p 7-41
Hüppop O, Dierschke J, Exo KM, Fredrich E, Hill R (2006) Bird migration studies and potential collision risk with offshore wind turbines. Ibis 148:90-109

Hyrenbach KD, Henry MF, Morgan KH, Welch DW, Sydeman WJ (2007) Optimizing the width of strip transects for seabird surveys from vessels of opportunity. Mar Ornithol 35:29-38

Loewe P, Becker G, Brockmann U, Dick S and others (2006) Nordseezustand 2004. Jahresber Bundesamt Seeschifffahrt Hydrogr 40:1-217

> Louzao M, Hyrenbach KD, Arcos JM, Abelló P, Gil de Sola L, Oro D (2006) Oceanographic habitat of an endangered Mediterranean procellariiform: implications for marine protected areas. Ecol Appl 16:1683-1695

Manikowski S (1971) The influence of meterological factors on the behaviour of seabirds. Acta Zool Cracov 20: 581-667

Markones N (2007) Habitat selection of seabirds in a highly dynamic coastal sea: temporal variation and influence of hydrographic features. PhD dissertation, University of Kiel

Markones N, Garthe S, Dierschke V, Adler S (2008) Small scale temporal variability of seabird distribution patterns in the south-eastern North Sea. In: Wollny-Goerke K, Eskildsen K (eds) Marine mammals and seabirds in front of offshore wind energy. MINOS - Marine warm-blooded animals in North and Baltic Seas. Teubner, Wiesbaden, p 115-140

> Meynard CN, Quinn JF (2007) Predicting species distributions: a critical comparison of the most common statistical models using artificial species. J Biogeogr 34:1455-1469

Nicholls DG, Murray MD, Butcher E, Moors P (1997) Weather systems determine the non-breeding distribution of wandering albatrosses over southern oceans. Emu 97:240-244

Nilsson ALK, Alerstam T, Nilsson JÅ, Holberton RL (2006) Do partial and regular migrants differ in their responses to weather? Auk 123:537-547

Oksanen J, Kindt R, Legendre P, O'Hara N, Simpson GL, Stevens MHH (2008) Vegan: community ecology package, R package Version 1.11-4. Available at: http://cran. r-project.org/, http://vegan.r-forge.r-project.org/

R Development Core Team (2008) R: a language and environment for statistical computing. R Foundation for Statistical Computing, Vienna, Austria. Available at: www.Rproject.org

Richardson WJ (1990) Timing of migration in relation to weather: an updated review. In: Gwinner E (ed) Bird migration: physiology and ecophysiology. Springer, Berlin, p 78-101

Ridgill SC, Fox AD (1990) Cold weather movements of waterfowl in western Europe. International Waterfowl Research Bureau Special Publication 13:1-89

Ronconi RA, Burger AE (2009) Estimating seabird densities from vessel transects: distance sampling and implications for strip transects. Aquat Biol 4:297-309

Sandvik H, Coulson T, Sæther BE (2008) A latitudinal gradient in climate effects on seabird demography: results from interspecific analyses. Glob Change Biol 14:703-713

Schneider DC (1991) The role of fluid dynamics in the ecology of marine birds. Oceanogr Mar Biol Annu Rev 29:487-521

Schwemmer P, Garthe S (2008) Regular habitat switch as an important feeding strategy of an opportunistic seabird species at the interface between land and sea. Estuar Coast Shelf Sci 77:12-22

Skov H, Prins E (2001) Impact of estuarine fronts on the dispersal of piscivorous birds in the German Bight. Mar Ecol Prog Ser 214:279-287 
Spear LB, Ainley DG (1997) Flight behaviour of seabirds in relation to wind speed and direction. Ibis 139:221-233

Spruzen FL, Woehler EJ (2002) The influence of synoptic weather patterns on the at-sea behaviour of three species of albatrosses. Polar Biol 25:296-302

Stone CJ, Webb A, Barton C, Ratcliffe N and others (1995) An atlas of seabird distribution in north-west European waters. Joint Nature Conservation Committee, Peterborough

Tasker ML, Jones PH, Dixon T, Blake BF (1984) Counting seabirds at sea from ships: a review of methods employed and a suggestion for a standardized approach. Auk 101: 567-577

Thomas L, Laake JL, Strindberg S, Marques FFC and others (2006) Distance 5.0, Release 2. Research Unit for Wildlife Population Assessment, University of St. Andrews, St. Andrews. Available at: www.ruwpa.st-and.ac.uk/distance/

Editorial responsibility: Jacob González-Solís, Barcelona, Spain
Weimerskirch H, Guionnet T, Martin J, Shaffer SA, Costa DP (2000) Fast and fuel efficient? Optimal use of wind by flying albatrosses. Proc R Soc Lond B Biol Sci 267: 1869-1874

Wiltshire KH, Manly BFJ (2004) The warming trend at Helgoland Roads, North Sea: phytoplankton response. Helgol Mar Res 58:269-273

Wood SN (2006) Generalized additive models. An introduction with R. Chapman and Hall, London

Wood SN (2008) Fast stable direct fitting and smoothness selection for generalized additive models. J R Stat Soc B 70: 495-518

Woodcock AH (1940) Observations of herring gull soaring. Auk 57:219-224

Zuur AF, Ieno EN, Smith GM (2007) Analysing ecological data. Springer, Berlin

Submitted: September 22, 2008; Accepted: June 19, 2009

Proofs received from author(s): September 7, 2009 